DOI: $10.26693 / \mathrm{jmbs} 03.06 .279$

UDC $577.3+615.9$

Harasym N. P., Bishko-Moskalyuk O. I., Wozniak M. V., Mandzynets S. M., Sanahursky D. I.

\title{
STATE OF THE ANTIOXIDANT PROTECTION SYSTEM IN RATS ERYTHROCYTES UNDER THE INFLUENCE OF HISTAMINE AND SODIUM HYPOCHLORITE
}

\author{
Ivan Franko National University, Lviv, Ukraine
}

garasymnataly@gmail.com

Sodium hypochlorite is used in medicine as a detoxifier due to oxidation of toxins and metabolites. This substance is officially used for disinfection of tap water. The widespread use of drugs for the release and histamine metabolism in medical practice is based on the use of two groups of drugs: histamine receptor blockers and plasma cell membrane stabilizing. However, the negative side effect causes the search for other safe paths of inactivation and reduction of histamine content in biological tissues. Thus, it is important to study the safety of the use of sodium hypochlorite for the treatment of patients with allergic manifestations. The excessive allocation of histamine, which is easily oxidized, mast cells and blood basophils should be also taken into account. Study of safety using the sodium hypochlorite for treatment the patients with allergic manifestation and the excessive allocation of histamine is an acute problematic nowadays.

The purpose of the study was to investigate the influence of histamine (in doses of 1 and $8 \mu \mathrm{g} / \mathrm{kg}$ of body weight of animals) and sodium hypochlorite (in concentrations 5 and $20 \mathrm{mg} / \mathrm{l}$ ), as well as their simultaneous action on the enzyme and non-enzymatic levels of the antioxidant system of red blood cells in rats.

Material and methods. The test substances were administered to animals for 14 days. On the $1^{\text {st }}, 7^{\text {th }}$, $14^{\text {th }}$ and $21^{\text {st }}$ (rehabilitation) days animals were decapitated. We took blood red cells samples by centrifugation and conducted their hemolysis. In hemolysates, the activity of glutathione peroxidase was studied, catalase, glutathione-S-transferase, amount of reduced glutathione. The dispersion analysis was also conducted.

Results and discussion. The histamine in erythrocytes leads to a decrease in the activity of investigated enzymes and the content of reduced glutathione during the experiment, except for the 7th day of the experiment. Sodium hypochlorite causes the initial growth of activity of glutathione peroxidase with the next decreasing the activity. Glutathione-Stransferase is the least sensitive to the action of this substance. Sodium hypochlorite on the background of action of histamine disrupts the work of enzymes. At the first day of the experiment, a histamine influence on the activity of glutathione peroxidase, catalase, and the content of reduced glutathione was dominant, whereas the simultaneous administration of histamine and sodium hypochlorite was significantly influenced by glutathione-S-transferase activity.

Conclusion. The combined administration of substances had a significant effect on the activity of glutathione peroxidase on the $7^{\text {th }}$ and $14^{\text {th }}$ days of the experiment. Sodium hypochlorite affected the activity of catalase and the content of reduced glutathione.

Keywords: histamine, sodium hypochlorite, erythrocytes.

Research relation to the plans, programs and department themes. The work is a fragment of the research work "Prooxidant-antioxidant homeostasis and systems of membrane transport of bioobjects under the influence of physical and chemical factors" (scientific leader: Dr. of biological sciences, professor Sanahursky D.I., State registration number: 0116U001633).

Introduction. The primary function of erythrocytes is the delivery of oxygen, nitric oxide to the periphery, and carbon dioxide in the lungs. At the same time, these cells act as a circulating inactivator (sink) of products of oxidative and nitrosyl stress. In erythrocytes there is a high level of compounds that belong to the antioxidant system of protection: reduced glutathione, thioredoxin, vitamins $\mathrm{C}$ and $\mathrm{E}$, superoxide dismutase, thioredoxin reductase, catalase, glutathione peroxidase, glutathione reductase, oxydoreductase of the plasmatic membrane, methemoglobin reductase [1]. Glutathione antioxidant system, which includes glutathione peroxidase, glutathione-S-transferase, glutathione reductase, reduced glutathione, prevents the accumulation of toxic products of lipid peroxidation, plays an important role in detoxification, degradation and excretion of heterologous organic substances 
from the body [2]. Glutathione peroxidase neutralizes hydrogen peroxide, which is also intercepted by catalase.

Histamine, the first established mediator of allergy, is synthesized from the amino acid of histidine by decarboxylation. Histamine is found in granules of mast cells and basophils in the form of a complex with proteoglycans. The concentration of histamine in cells of the mucous coat is high ( $5 \mathrm{mg} / 100$ cells). In thrombocytes and basophils it is significantly less $(1 \mathrm{mg} / 100$ cells). The amount of histamine in the blood fluctuates during the day and averages $300 \mathrm{pg} / \mathrm{ml}$. The peak of histamine action in 1-2 minutes after its release, the duration of action is up to 10 minutes. The main inactivation pathways of the biogenic amine are the deamination by histaminase and methylation with $\mathrm{N}$ methyltransferase. A part of histamine binds to proteins of serum blood. Released from the depot, histamine acts via H1-, H2-, H3-, H4-receptors. For example, stimulation of $\mathrm{H} 1$-receptors causes a contraction of smooth muscles of the bronchus and gastrointestinal tract increased vascular permeability, increased secretion of mucus by the glands of the nasal mucosa, paresis of peripheral pre-capillaries of the skin, irritation of the nerve endings and itching. Histamine plays an important role in the regulation of the immune response, since $\mathrm{H} 2$-receptors are present on cytotoxic T-lymphocytes and basophils, and stimulation of this receptor by histamine leads to the activation of T-suppressors [3]. Matthew C. Wagner et al. showed that the release of histamine contributes to the attachment of falx cells of erythrocytes to the endothelium in postcapillary veins and vasocclusion. The adhesion of the falx cells of erythrocytes caused by histamine is dependent on the simultaneous stimulation of histamine $\mathrm{H} 2$ - and H4-receptors and the expression of endothelial P-selectin [4]. There are a number of inflammatory mediators that are produced by leukocytes, mainly neutrophils, with bacterial invasion. Neutrophils produce and release eosinophilic cationic protein and histamine, two important mediators of inflammation. In patients with periodontitis, neutrophils form histamine in response to the action of lipopolysaccharides [5]. Nowadays, it remains unknown whether there are erythrocyte receptors for histamine, whether erythrocytes can adsorb histamine, and also how histamine acts on the antioxidant defense system in them.

Sodium hypochlorite ( $\mathrm{SH}$ ) used in medicine as a detoxifier due to oxidation of toxins and metabolites. This substance is officially used for disinfection of tap water [6]. The widespread use of drugs for the release and histamine metabolism in medical practice is based on the use of two groups of drugs: histamine receptor blockers and plasma cell membrane stabiliz- ing. However, the negative side effect causes the search for other safe paths of inactivation and reduction of histamine content in biological tissues [7]. Thus, it is important to study the safety of the use of $\mathrm{SH}$ for the treatment of patients with allergic manifestations, and also the excessive allocation of histamine, which is easily oxidized, mast cells and blood basophils.

$\mathrm{SH}$ reduces its content in the blood of people in the case of severe poisoning with psychopharmacological substances [8]. The literature does not contain information on the direct effect of histamine on the antioxidant state of erythrocytes. Unresolved remains the issue of mutual action of histamine and $\mathrm{SH}$. Previously, we studied the influence of histamine and $\mathrm{SH}$ on various tissues of the body: lungs, heart, blood plasma, kidneys, liver [9, 10].

The Purpose of our Work was to investigate the influence of histamine and $\mathrm{SH}$, as well as their simultaneous action on the enzymatic and non- enzymatic levels of the antioxidant system of red blood cells in rats.

Material and Methods. Experiments were conducted on outbred white male rats (Rattus norvegicus $\mathrm{f}$. Domesticus) for 21 days. The weight of animals was $180-220 \mathrm{~g}$. The animals were selected on the basis of analogies, 20 animals in each group. The 1st control group included intact animals. The animals of the second and third groups received subcutaneous injections of histamine solutions in doses of 1 and $8 \mu \mathrm{g} / \mathrm{kg}$ of body weight of animals $(0,01 \%$ histamine dihydrochloride solution was used as a stock solution; manufacturer - Limited Liability Company «Immunolog», Ukraine, Vinnytsya) respectively. The chosen doses corresponded to those causing pathological manifestations in experimental conditions [11]. Animals of the 4 th and 5th groups were given a solution of $\mathrm{SH}$ (5 and $20 \mathrm{mg} / \mathrm{l}$, respectively, made at the Ukrainian State Chemical Technology University, Dnipropetrovsk) during this period. In addition, four more groups were formed. The animals of these groups were simultaneously injected by histamine and sodium hypochlorite in different combinations of the indicated concentrations. On the $1^{\text {st }}, 7^{\text {th }}, 14^{\text {th }}$ and $21^{\text {st }}$ (rehabilitation) days five animals from each group were decapitated under light ether anesthesia in compliance with the European Convention for the Protection of vertebrate animals used for experimental and scientific purposes (Strasbourg, France 1986) and according to the recommendations of the "Bioethical examination of preclinical and other scientific researchers performed on animals" (Kyiv, Ukraine, 2006). We took blood red cells samples by centrifugation and conducted their hemolysis with distilled water. In hemolysates, the activity of glutathione peroxidase was studied (EC 1.11.1.9; glutathione: hydrogen-peroxide- 
oxydoreductase) [12], catalase (EC 1.11.1.6; hydrogen-peroxide:hydrogen-peroxide-oxydoreductase) [13], glutathione-S-transferase (EC 2.5.1.18; RX:glutathione-R-transferase) [14], amount of reduced glutathione (GSH) [15]. The amount of protein in each sample was determined by Lowry method.

Statistical processing of the research results and two-factor dispersion analysis were performed using the Excel-2010 program for Windows. The significance probability of the difference between the statistical characteristics of two alternative sets of data was estimated by calculating Student coefficient. The significant difference was considered for $p \geq 0,95$, $p \geq 0,99, p \geq 0,999$.

Results and Discussion. It is known that erythrocytes possess high sensitivity to chemicals substances [16]. We found out that the histamine in concentrations of 1 and $8 \mu \mathrm{g} / \mathrm{kg}$ in rats' erythrocyte hemolysates led to decreasing the activity of glutathione peroxidase at $1^{\text {st }}$ and $14^{\text {th }}$ day of the experiment (on 89 and $46 \%-1^{\text {st }}$ day, 53 and $63 \%-14^{\text {th }}$ day respectively). After the rehabilitation period, the activity of this enzyme decreased (Fig. 1, A). Histamine caused

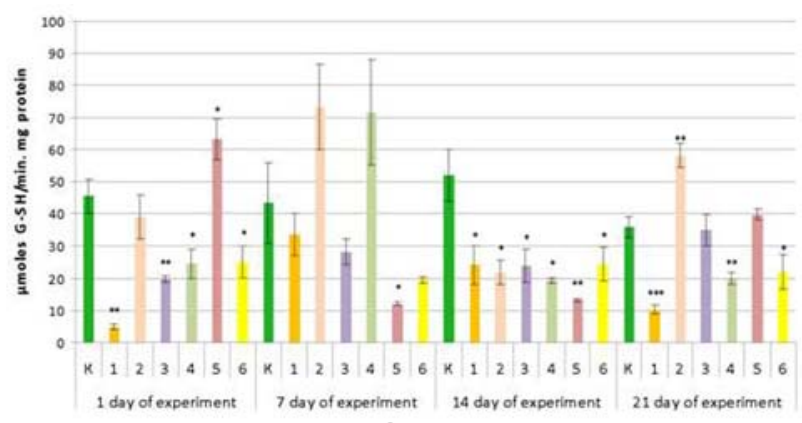

(A)

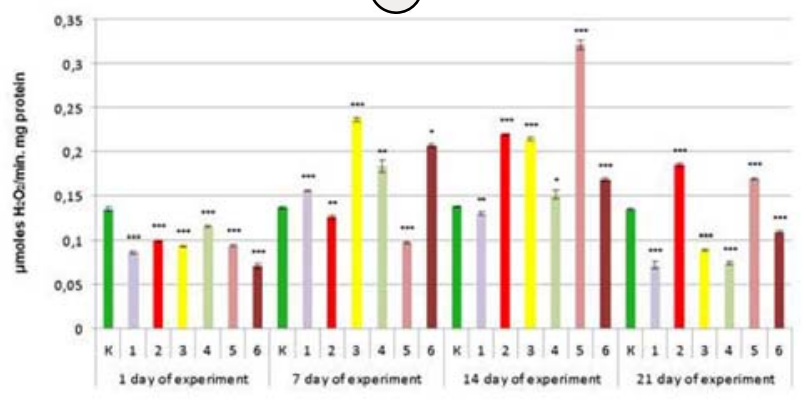

(B)

Fig. 1 - The activity of glutathione peroxidase (A) and catalase $(B)$ in rats erythrocyte hemolysates on $1^{\text {st }}, 7^{\text {th }}, 14^{\text {th }}$ and $21^{\text {st }}$ day of the experiment. Here and on Fig. 2:

$\mathbf{K}$ - control; 1, $\mathbf{4}$ - for the histamine action, respectively, at a dose of 1 and $8 \mu \mathrm{g} / \mathrm{kg}$ body weight of animals; $2, \mathbf{5}$ - with simultaneous exposure to sodium hypochlorite $(5 \mathrm{mg} / \mathrm{l})$ and histamine ( 1 and $8 \mu \mathrm{g} / \mathrm{kg}$ body weight of animals, respectively); 3, 6 - with simultaneous exposure to sodium hypochlorite $(20 \mathrm{mg} / \mathrm{l})$ and histamine $(1$ and $8 \mu \mathrm{g} / \mathrm{kg}$ body weight of animals, respectively). ${ }^{*} p \geq 0,95$; ${ }^{* *} p \geq 0,99$; ${ }^{\star \star *} p \geq 0,999$ a decreasing in the activity of catalase in the $1^{\text {st }}$ and $21^{\text {st }}$ (rehabilitation) days of the experiment.

However, on the $7^{\text {th }}$, the growth of catalase activity was found to be $13 \%$ and $35 \%$, respectively, due to histamine effects of lower and higher concentrations in accordance. At the $14^{\text {th }}$ day of the action of the biogenic amine in a low concentration, a slight, but a significant reduction in the activity of catalase was detected (by 6\%), while in high concentration we detected the increased activity of catalase by $10 \%$ (Fig. 1, B). The simultaneous decrease in the activity of glutathione peroxidase and catalase indicates a decreasing the content of hydrogen peroxide in erythrocytes, as well as lipid hydroperoxides since these enzymes intercept hydrogen peroxide and glutathione peroxidase also neutralizes hydroperoxides. At the $7^{\text {th }}$ day, an increase in the activity of catalase on the background of the normal work of glutathione peroxidase was detected. This indicates that a significant amount of $\mathrm{H}_{2} \mathrm{O}_{2}$ is formed at this time. It is known that glutathione peroxidase neutralizes small amounts of hydrogen peroxide, while catalase activity increases at significant concentrations of this substrate.

We also noticed a reduction in the activity of glutathione-S-transferase at the $7^{\text {th }}$ and $14^{\text {th }}$ day of the experiment after injection of histamine at a concentration of $1 \mu \mathrm{g} / \mathrm{kg}$. Biogenic amine in higher concentrations caused a decrease (by $57 \%$ ) the activity of this enzyme at the 7th day, as well as after the rehabilitation period (58\%, Fig. 2, A). The glutathione-Stransferase and reduced glutathione play an important role in the detoxification function of red blood cells. Thus, aldehyde dehydrogenase, aldehyde reductase, and glutathione-S-transferase are involved in the removing of aldehydes (which are capable of interacting with proteins and nucleic acids, changing their functional properties). However, the main path of catabolism is conjugation with glutathione [17]. It should be noted that this enzyme also neutralizes drugs, harmful compounds. Reduced glutathione-S-transferase activity in erythrocytes due to histamine exposure is a negative phenomenon since in this case the detoxification function of these cells is disturbed.

The content recovered glutathione significantly decreased in erythrocytes by the histamine action in both concentrations during the experiment. It was noted every day, except for the $7^{\text {th }}$ day, when its content rose (by 21 and $13 \%$ accordingly to at a concentration of 1 and $8 \mu \mathrm{g} / \mathrm{kg}$; Fig. 2, B).

The decreased activity of glutathione peroxidase by histamine action was due to a lowered content of reduced glutathione. It is well-known that glutathione peroxidase works in the presence of sufficient amounts of glutathione in the medium. Probably histamine leads to the formation of reactive oxygen 


\section{Біологічні науки}

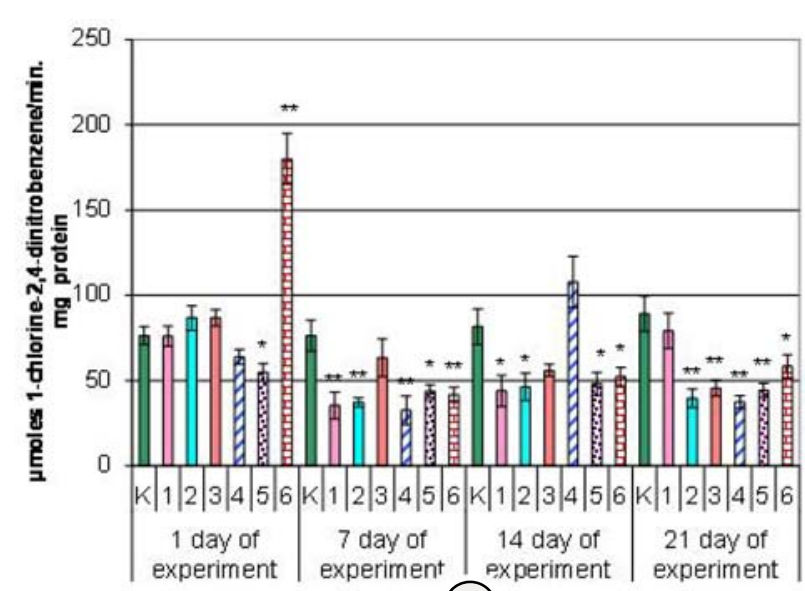

(A)

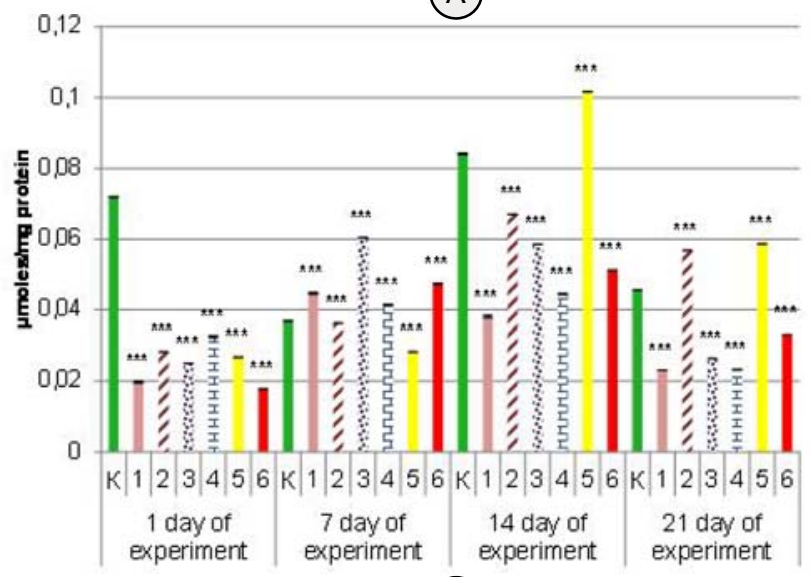

(B)

Fig. 2. The glutathione-S-transferase activity $(A)$ and the content of reduced glutathione $(B)$ in rats erythrocyte hemolysates on $1^{\text {st }}, 7^{\text {th }}, 14^{\text {th }}$ and $21^{\text {st }}$ day of the experiment. ${ }^{*} p \geq 0,95 ;{ }^{* *} p \geq 0,99 ;{ }^{* *} p \geq 0,999$

species and harmful compounds in the plasma, which adsorbs by erythrocytes and neutralizes by GSH, reducing its pool. Significant oxidation of intracellular GSH promotes oxidative damage to proteins and lipids and also endangers the structural integrity and viability of red blood cells. The GSH redox status of erythrocytes not only contributes to the growth of their oxidative potential and increases hemolysis, but also reduces the bioavailability of nitric oxide in zones of oxidative damage [1]. The histamine had a special (more adaptive) effects on the antioxidant system of red blood cells on the $7^{\text {th }}$ day of the experiment. These effects consisted in returning to the normal activity of glutathione peroxidase, increasing activity of catalase decreasing glutathione-S-transferase activity and increasing GSH content. The concentration of reduced glutathione in erythrocytes is $2-4 \mathrm{mM}$. Approximately $99,5 \%$ of GSH blood is present in erythrocytes in the amount of $8,77 \mathrm{mg} / \mathrm{g}$ hemoglobin, or at a concentration of 2,73-3,50 mmol/l [1]. It was shown that the glutathione peroxidase activity, glutathione-S- transferase, glutathione reductase and GSH content significantly decreased in experimental animals after 3 hours after administration of $0,1 \mathrm{ml}$ of histamine in the middle ear as a proinflammatory factor for the development of otitis, in samples of red blood cells from the middle ear inflammatory fluid guinea pigs compared to control [18]. Consequently, our studies are consistent with the literature data. Ucuncu $\mathrm{H}$. suggests that histamine causes the inflammatory process, during which reactive oxygen species are formed, and the glutathione link of the antioxidant system reacts in protocols with histamine otitis and with the use of antioxidant agents on the background of inflammatory reactions [19].

Thus, histamine in erythrocytes causes a predominant decreasing in the activity of antioxidant system enzymes during the experiment, except for the $7^{\text {th }}$ day of the experiment.

The $\mathrm{SH}$ in a concentration of $5 \mathrm{mg} / \mathrm{l}$ lead to increase the activity of glutathione peroxidase by $229 \%$ on the $7^{\text {th }}$ day, with next decreasing the activity on the $14^{\text {th }}$ day (by $51 \%$ ). Along with this, the activity of catalase in erythrocytes of rats is insignificant, but decreases reliably both on 1st, and on the 7 th day of the experiment. After 14-day using water with $\mathrm{SH}(5 \mathrm{mg} / \mathrm{l})$ for the drink, the activity of catalase increased by $81 \%$ compared with control. Probably SH in this concentration on the $7^{\text {th }}$ day of the experiment neutralizes large amounts of hydroperoxides. The action of $\mathrm{SH}(5 \mathrm{mg} / \mathrm{l})$ after the fourteen-day led to the formation of significant amounts of hydrogen peroxide, resulting in an increase in catalase activity at that time (Fig. 3, A, B). The action of $\mathrm{SH}$ at a concentration of $20 \mathrm{mg} / \mathrm{ll}$ led to the activity of glutathione peroxidase increases for 1 day $(80 \%)$, however, at the 7 th and 14 th day showed the opposite effect. At the first and the 14th day the activity of the catalase enzyme increases by 9 and $73 \%$, respectively, with the action of the $\mathrm{SH}$ at the higher concentration. Consequently, the action of $\mathrm{SH}$ in the concentration of $20 \mathrm{mg} / \mathrm{l}$ caused a negative oxidative effect at the initial stage of the study. Notice that $\mathrm{SH}$ at both concentrations led to the formation of higher concentration of hydrogen peroxide more than normal after the prolonged action. Hydrogen peroxide in the blood may be formed outside the erythrocytes. $\mathrm{H}_{2} \mathrm{O}_{2}$ can penetrate them through diffusion, where it is deactivated by catalase [20]. $\mathrm{Fe}^{2+}$ hemoglobin is oxidized to $\mathrm{Fe}^{3+}$ (methemoglobin, MetHB) under the action of oxidants (amyl nitrite, aniline, nitrobenzene, nitrates and nitrites, thiosulfates, ferricyanide). Probably the $\mathrm{SH}$ accompanies such a process because it acts as a strong oxidizer. Every day $0.5 \%$ of all hemoglobin is converted into methemoglobin in the body. But in erythrocytes, there is an enzyme called methemoglobin reductase, which catalyzes the restoration of 


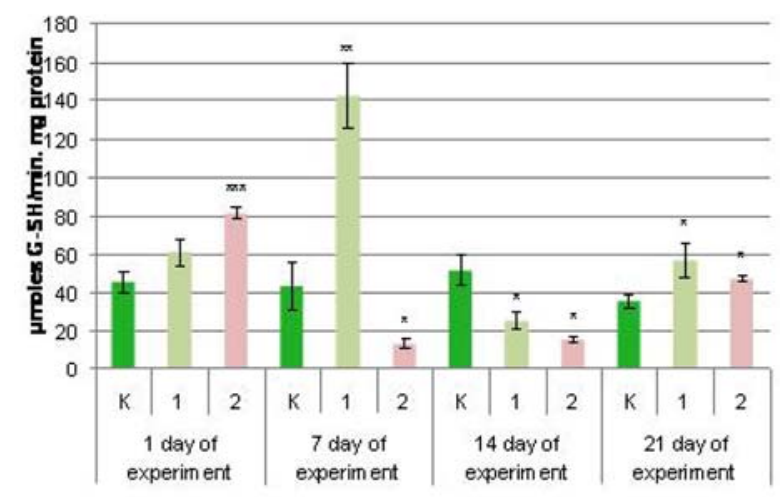

(A)

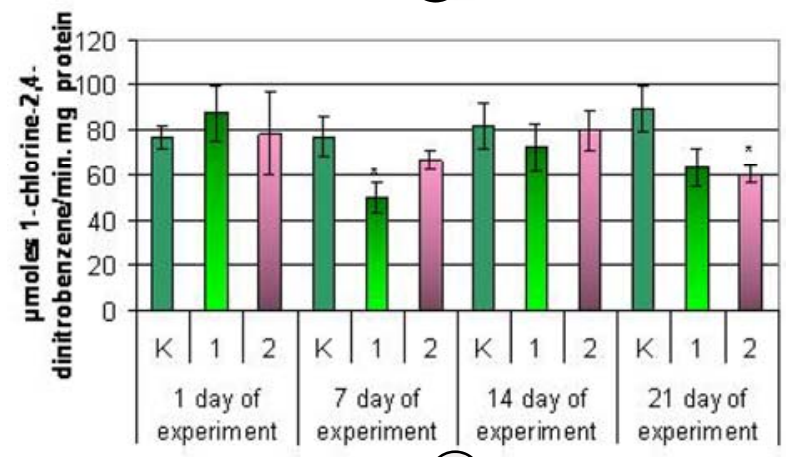

(C)

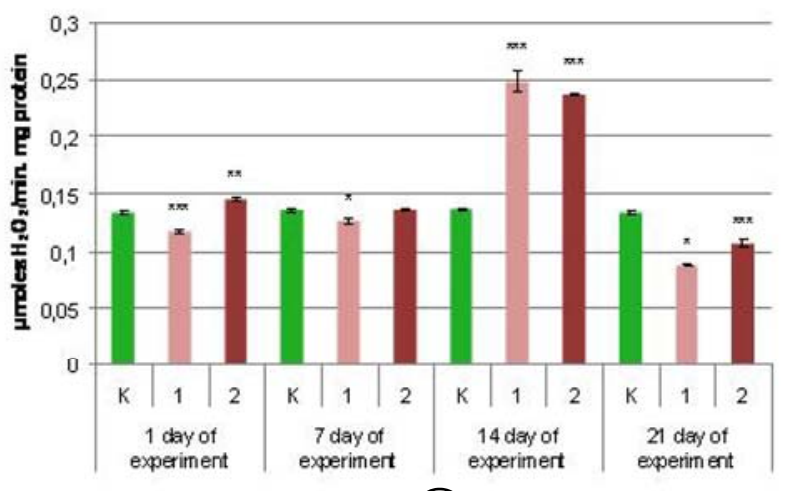

(B)

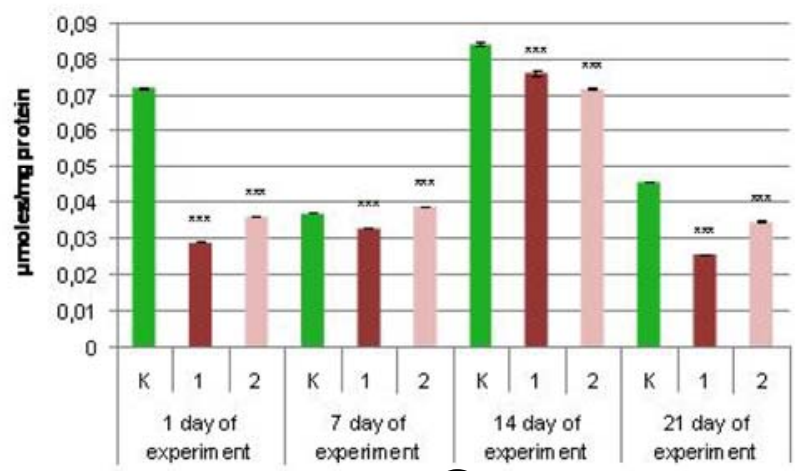

(D)

Fig. 3 - The activity of glutathione peroxidase $(A)$, catalase $(B)$, glutathione-S-transferase $(C)$ and the content of reduced glutathione $(D)$ in rats erythrocyte hemolysates on $1^{\text {st }}, 7^{\text {th }}, 14^{\text {th }}$ and $21^{\text {st }}$ day of the experiment. $\mathrm{K}-$ control; $\mathbf{1}, \mathbf{2}-$ for the sodium hypochlorite action, respectively, at a concentrations 5 i $20 \mathrm{mg} / \mathrm{l}$. ${ }^{*} p \geq 0,95 ;{ }^{* *} p \geq 0,99 ;{ }^{* * *} p \geq 0,999$

methemoglobin to hemoglobin, so the actual concentration of methemoglobin in the blood is normally low. The oxidation of hemoglobin to methemoglobin by oxygen causes the formation of a superoxide anion radical $\left(\mathrm{O}^{--}\right)$. Superoxide radical, which exhibits toxic activity under the action of superoxide dismutase, is converted into $\mathrm{H}_{2} \mathrm{O}_{2}$. The latter decomposes under the influence of catalase and peroxidase of red blood cells. After seven days of rehabilitation, the activity of glutathione peroxidase increases, while catalase it decreases (Fig. 3, A, B). This time, the work of the antioxidant system in the erythrocytes is probably aimed at the destruction of hydroperoxides, and excessive formation of hydrogen peroxide no longer occurs.

By studying the activity of glutathione-Stransferase, it was found out that $\mathrm{SH}$ only at a concentration of $5 \mathrm{mg} / \mathrm{l}$ caused the decrease its activity on the $7^{\text {th }}$ day by $35 \%$. Such results indicate that in erythrocytes, the action of $\mathrm{SH}$ does not produce harmful substrate compounds for this enzyme. It is important to note that $\mathrm{SH}$ caused a decreasing in the content of reduced glutathione during the experiment, except for the effect of this compound at a concentration of 20 $\mathrm{mg} / \mathrm{l}$ on the $7^{\text {th }}$ day (increasing by $5 \%$ ). Therefore, we may conclude that the influence of $\mathrm{SH}$ in the red blood cells formed substances that intercept the recovered glutathione and its pool is reduced (Fig. 3, C, D). We may include aldehydes to these substances.

Thus, SH causes the initial growth of activity of glutathione peroxidase with its subsequent decrease. The fourteen-day administration of this substance causes an increase in the activity of catalase, while the content of reduced glutathione decreases during the experiment. After rehabilitation, the activity of glutathione peroxidase increased, and the activity of catalase and the content of reduced glutathione decreased compared to control group in erythrocytes. The most inert to this investigating substance was glutathione-S-transferase. After analysis of these research results, we suppose that in erythrocytes, $\mathrm{SH}$ acts as an oxidizer, resulting in the formation of various active forms of oxygen and free radicals, which are intercepted by the enzymatic and non-enzymatic links of the antioxidant system. The formation of hypohalites in this case (by the effect on red blood cells of control rats) probably does not occur, as evidenced by the activity of glutathione-S-transferase, an enzyme that neutralizes harmful substances. There is also no damage to the structure of enzymes, since their 
activity fluctuates throughout the experiment and their work can be interconnected.

We had found out that the combined action of $\mathrm{SH}$ at the concentration of $5 \mathrm{mg} / \mathrm{l}$ and histamine at the concentration of $8 \mu \mathrm{g} / \mathrm{kg}$ led to the violation of the activity of glutathione peroxidase from the first day. So, at this day, the activity of the enzyme increased by $39 \%$, but already at the $7^{\text {th }}$, it decreased by $72 \%$ compared with to the control. Reduction of glutathione peroxidase activity occurred on the $14^{\text {th }}$ day in the groups of rats, that were administered the histamine in both concentrations and $\mathrm{SH}(5 \mathrm{mg} / \mathrm{l})$ simultaneously. When we studied catalase in erythrocytes it was noted that its activity decreased on the $7^{\text {th }}$ day by about $30 \%$, however, since the $14^{\text {th }}$ day, was found the opposite effect the action of $\mathrm{SH}$ in the concentration 5 $\mathrm{mg} / \mathrm{l}$ and histamine $(1$ and $8 \mu \mathrm{g} / \mathrm{kg}$ ). After analyzing the work of these two enzymes, we assumed that the concentration of hydrogen peroxide significantly increases in erythrocytes since the $14^{\text {th }}$ day and catalase reacts with it. The administration of $\mathrm{SH}(5 \mathrm{mg} / \mathrm{l})$ on the background of histamine action of both concentrations caused a decreasing the activity of glutathioneS-transferase over the course of the experiment by an average of $50 \%$. It should be noted that the activity of this enzyme is lowered by the action of histamine, while the simultaneous effect of biogenic amine and $\mathrm{SH}$ (5 mg/l) only enhances such an effect. We established a decreasing in the content of reduced glutathione till the 7th day by the action of histamine and $\mathrm{SH}(5 \mathrm{mg} / \mathrm{l})$. By the $14^{\text {th }}$ day of the experiment, the content of reduced glutathione had already increased by $21 \%$ with simultaneous exposure $\mathrm{SH}(5 \mathrm{mg} / \mathrm{l})$ and histamine at a concentration of $8 \mu \mathrm{g} / \mathrm{kg}$. After the rehabilitation period, the GSH content increased in the groups of rats that received histamine in both studied concentrations and $\mathrm{SH}(5 \mathrm{mg} / \mathrm{l})$. Consequently, $\mathrm{SH}$ at the concentration of $5 \mathrm{mg} / \mathrm{l}$ against the background of histamine action violated function the antioxidant system with a predominant inhibition of glutathionerelated enzymes (Fig. 1, 2). The most pronounced negative action was on glutathione-S-transferase.

The combined action of $\mathrm{SH}$ at a concentration of $20 \mathrm{mg} / \mathrm{l}$ and histamine $(1$ and $8 \mu \mathrm{g} / \mathrm{kg}$ ) resulted to decrease in the activity of glutathione peroxidase, catalase and reduced glutathione on the $1^{\text {st }}$ day of the experiment in erythrocytes hemolysates. On the $7^{\text {th }}$ day the simultaneous action of the studied substances, the activity of glutathione peroxidase returns to the limits of control, and the activity of catalase and the content of reduced glutathione - increase. The growth of GSH content can be explained by not using glutathione peroxidase and glutathione-S-transferase, as well as the absence of substrate compounds for it. After two weeks of substances administration in eryth- rocyte hemolysates, the activity of glutathione peroxidase, glutathione-S-transferase and the content of reduced glutathione decreased, while the activity of catalase remained high. The growth of the activity of catalase, as already noted, indicates the formation of the high hydrogen peroxide concentrations.

It is known that in erythrocytes there is a high content of catalase [21]. After the rehabilitation period, the activity of the studied enzymes and the content of GSH were reduced (Fig. 1, 2). Consequently, $\mathrm{SH}$ at a concentration of $20 \mathrm{mg} / \mathrm{l}$ on the background of histamine action caused a more pronounced negative effect (compared to the simultaneous action of low concentration of $\mathrm{SH}$ ) on the antioxidant defense system, as evidenced by the increasing activity of catalase (and hence the formation of high concentrations of hydrogen peroxide) and decreasing activity of glutathione peroxidase and glutathione-S-transferase. Glutathione peroxidase, an enzyme that depends on selenium micronutrients, plays a decisive role in lowering lipids and hydrogen peroxide. If the activity of glutathione peroxidase decreases, the content of hydrogen peroxide increases, which leads to direct damage to the cells and activates the proinflammatory pathways [22]. In the cell, the role of glutathione-Stransferase is to provide oxidative-reducing homeostasis by restoring the cysteine residues of proteins, which prevents their degradation after the action of endogenous (oxidative or nitrous) or exogenous (xenobiotic) factors, and ligament binding to the kinase pathways (in particular, JNK), that is, the signaling mechanisms of survival and death of cells [23].

It was noted that $\mathrm{SH}$ at a concentration of $0,1 \mathrm{mg} / \mathrm{l}$ in the $7^{\text {th }}$ day in Solea senegalensis causes hypertrophy, oxidative stress [24]. Sodium hypochlorite $(\mathrm{NaClO})$, which is discharged by the power plants in the receiving waters, causes 1, 3, 7 and 14 days of Mytilus galloprovincialis in the digestive gland and gland of the moth, pathological reaction, as well as changes in the activity of glutathione-S-transferase enzymes, catalase, acetylcholinesterase and level peroxide oxidation of lipids. Influence of $\mathrm{NaClO}$ causes a toxicological reaction [25]. We assume that simultaneous administration of histamine to rats and $\mathrm{SH}$ in the body produce harmful substances that damage the enzymes (glutathione-S-transferase, glutathione peroxidase). These include nitriles and carbonyl compounds, as well as chloramines.

The two-factor dispersion analysis showed that at the $1^{\text {st }}$ day of the experiment, the dominant influence of histamine was on the activity of glutathione peroxidase, catalase and the content of reduced glutathione where the share of influence of the factors were 46.66 and $41 \%$ respectively. Probably the short-term action of histamine causes the formation of free radicals due 
to the violation of the prooxidant-antioxidant homeostasis of blood, in particular, erythrocytes. Thus, the simultaneous administration of histamine and $\mathrm{SH}$ (share of influence of the factor is equal to $46 \%$ ) significantly influences the activity of glutathione-Stransferase. The combined effect of histamine and $\mathrm{SH}$ induces a change in the activity of glutathione peroxidase at the $7^{\text {th }}$ and $14^{\text {th }}$ day of the experiment (share of influence of the factors are 44 and $30 \%$, respectively). At these days of the experiment, the $\mathrm{SH}$ had a major influence on the activity of catalase and the content of reduced glutathione. $\mathrm{NaClO}$ is a powerful oxidizer, due to which free radicals are formed, which are inactivated precisely by catalase and reduced glutathione. GSH is an important factor in the formation of the thiol component of the redox buffer of most differentiated cells, including erythrocytes [1]. A significant part of the effects on the activity of glutathione peroxidase and glutathione-S-transferase in rat erythrocytes was unaccounted factors (Fig. 4).

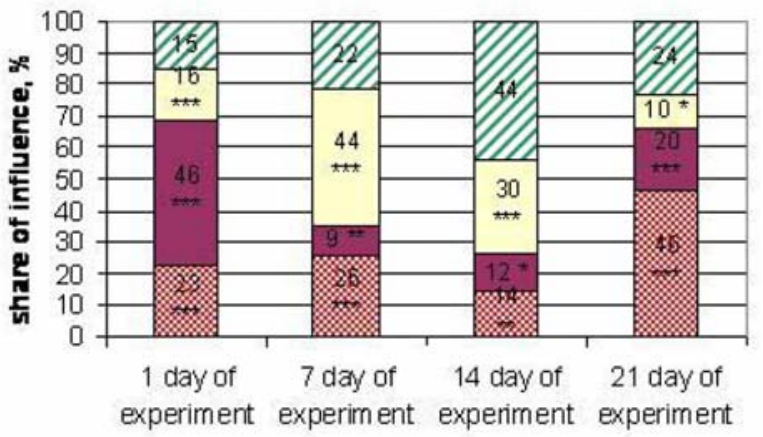

(A)

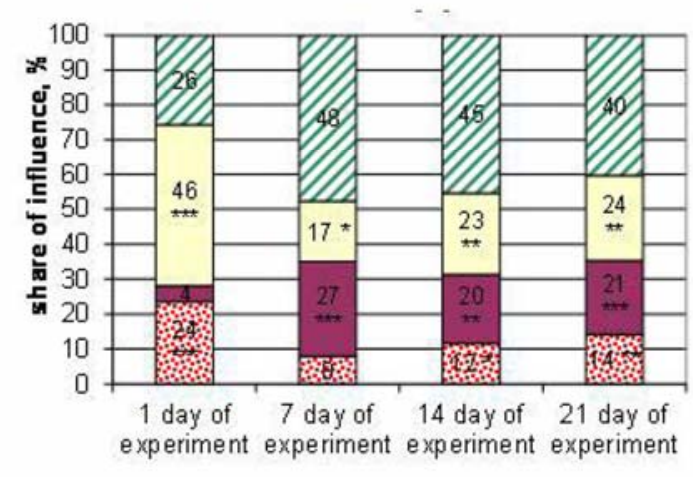

(C)

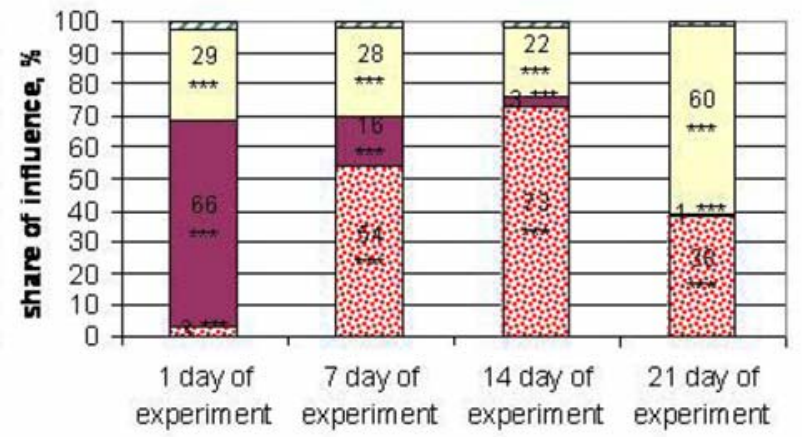

(B)

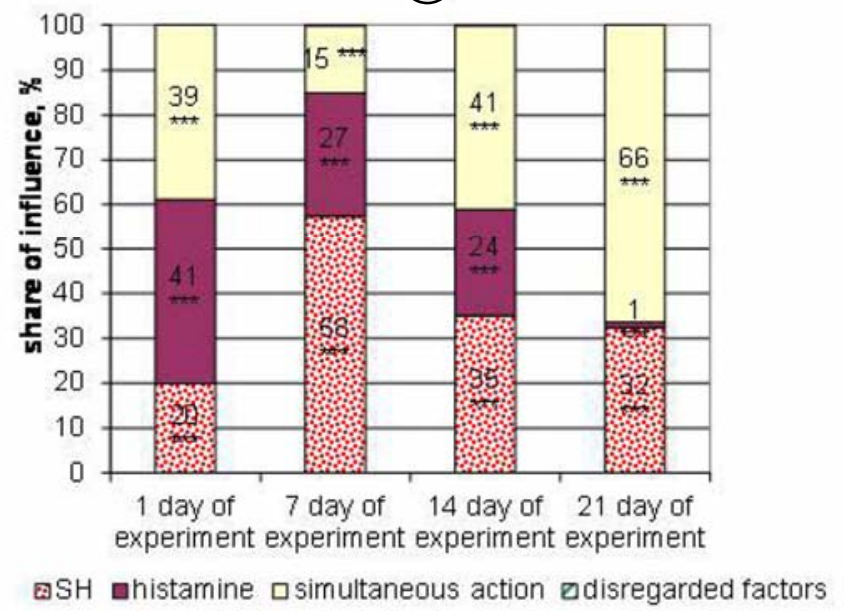

(D)

Fig. 4. - Results of two-factor dispersion analysis of indicators of antioxidant state (A - glutathione peroxidase; B - catalase; C - glutathione-S-transferase; D - reduced glutathione) in rats erythrocyte hemolysates for the histamine and sodium hypochlorite action. ${ }^{*} p \geq 0,95 ;{ }^{* *} p \geq 0,99 ;{ }^{* * *} p \geq 0,999$

Conclusion. Consequently, histamine in erythrocytes leads to a predominant decrease in the activity of enzymes of the antioxidant system and the content of reduced glutathione during the experiment, except for the $7^{\text {th }}$ day. SH caused the initial growth of activity of glutathione peroxidase with its subsequent decreasing. At the fourteenth-day injection of $\mathrm{SH}$ led to increasing the activity of catalase, but the content of reduced glutathione decreased during the experiment. The least sensitive to the action of $\mathrm{SH}$ was glutathione
-S-transferase. $\mathrm{SH}$ at a low concentration (5 mg/l) against the background of histamine action violates the function of enzymes antioxidant system with the predominant inhibition of glutathione-related enzymes. $\mathrm{SH}$ at a high concentration $(20 \mathrm{mg} / \mathrm{l})$ on the background of histamine action had a more pronounced negative effect on the antioxidant defense system, as evidenced by the increased activity of catalase and decreased the activity of glutathione peroxidase and glutathione-S-transferase. The dispersion analysis 
showed that on the 1st day of the experiment histamine had the main effect on the activity of glutathione peroxidase, catalase and on the content of reduced glutathione, whereas, the simultaneous administration of histamine and $\mathrm{SH}$ had the effect on the activity of glutathione-S-transferase. The combined administration of histamine and $\mathrm{SH}$ had a powerful effect on the activity of glutathione peroxidase on the $7^{\text {th }}$ and $14^{\text {th }}$ day of the experiment, $\mathrm{SH}$ acted on the activity of catalase and the content of reduced glutathione.

Prospects of further research. In future the perspective direction of research is in determination of intensity of lipid peroxydation in erythrocytes of rats under the action of histamine and sodium hypochlorite.

\section{References}

1. Buko IV, Polonetsky LZ, Mrochek AG, Moiseenok AG. Antioxidant status and glutathione redox potential of erythrocytes in patients with acute coronary syndrome. Ukr Biochem J. 2014; 86(3): 114-24. [Ukrainian] http://dx.doi. org/10.15407/ubj86.03.114

2. Gayda LM, Drobinska OV, Tymoshenko MA, Ostapchenko LI. The glutathione-dependent enzyme activity in rat parietal cells and hepatocytes under experimental atrophic gastrirtis. Physics of the Alive. 2008; 16(1): 144-8. [Ukrainian]

3. Novik GA. Mechanisms of allergic reactions and methods of allergic examination in clinical practice. The educationalmethodical manual is edited by the honored worker of science of the Russian Federation, professor IM Vorontsov. SPb: Publication GPMA; 2004. 76 p. [Russian]

4. Wagner MC, Eckman JR, Wick TM. Histamine increases sickle erythrocyte adherence to endothelium. Br J Haematol. 2006; 132(4): 512-22. PMID: 16412024. doi: 10.1111/j.1365-2141.2005.05880.x

5. Ribas D, Fernández-Carranco MC, Hajji N, Bobadilla P, Monteseirín J. Eosinophil cationic protein and histamine production by neutrophils from patients with periodontitis. J Periodontol. 2018; 89(2): 228-34. doi: 10.1902/ jop.2017.160679

6. Lebedev AT, Shaydullina GM, Sinikova NA, Harchevnikova NV. GC-MS comparison of the behavior of chlorine and sodium hypochlorite towards organic compounds dissolved in water. Water Res. 2004; 38: 3713-18. PMID: 15350423. doi: 10.1016/j.watres.2004.06.007

7. Chekman ES. Clinical pharmacology of antihistaminic drugs. Med of railw Transp of Ukr. 2002; 2: 58-61. [Ukrainian]

8. Petrov SE. Application of sodium hypochlorite in clinical toxicology. Dissertation for the degree of Doctor of Medical Sciences. Moscow: 2005. [Russian]

9. Bishko OI, Harasym NP, Sanahursky DI. The system of antioxidant defence in liver and kidneys of rat at influence of histamine and sodium hypochlorite. Exper Clin Physiol Biochem. 2014; 3: 33-43. [Ukrainian]

10. Bishko OI, Harasym NP, Sanahurs'kyj DI. Antioxidant defense system state in blood plasma and heart muscle of rats under the influence of histamine and sodium hypoclorite. Uk Biochem J. 2014; 86(6): 56-65. [Ukrainian] http:// dx.doi.org/10.15407/ubj86.06.056

11. Komarenko VI, Terekhov AA, Vorobyova AP. Investigation of the role of H1-receptor responses in rat liver portal vessels to histamine. Cherk Nat Univ B Khmelnitsky Biol Sci Series. 2008; 128: 54-8. [Ukrainian]

12. Moin VM. A simple and specific method for determining the activity of glutathione peroxidase in erythrocytes. Lab Bus. 1986; 2: 724-7. [Russian]

13. Koroljuk MA, Ivanova LI, Mayorov IG. Method for determination of catalase activity. Labor Work. 1988; 1: 16-9. [Russian]

14. Habig WH, Parst MJ, Jakobv WB. Glutathione-S-transferases. The first enzymatic step in mercapturie acid formation. Journal of Biological Chemistry. 1974; 249(22): 7130-9. PMID: 4436300. doi: 10.12691/jfnr-3-6-1

15. Sibirna NO, Majevska OM, Barska ML. Investigation of certain biochemical indices under conditions of oxidative stress. Lviv: Publishing Center of I Franko LNU; 2006. 60 p. [Ukrainian]

16. Apihtina OL. Investigation of membrane toxic effect of heavy metals on the model of erythrocytes of blood in vitro. Modern problems of toxicology. 2011; 1-2: 65-9. [Ukrainian]

17. Borovskaya MK, Kuznetsov EE, Gorokhova VG, Koriakina LB, Kurilskaya TE, Pivovarov Jul. Structural and functional characteristics of membrane's erythrocyte and its change at pathologies of various genesis. Bulletin VSSC of the RAMS. 2010; 3(73): 334-54. [Russian]

18. Taysi S, Ucuncu H, Elmastas M, Aktan B, Emin Buyukokuroglu M. Effect of melatonin on lipid peroxidation, glutathione and glutathione-dependent enzyme activities in experimental otitis media with effusion in guinea pigs. J Pineal Res. 2005; 39(3): 283-6. PMID: 16150109. https://doi.org/10.1111/j.1600-079X.2005.00252.x

19. Ucuncu H, Taysi S, Aktan B, Buyukokuroglu ME, Elmastas M. Effect of dantrolene on lipid peroxidation, lutathione and glutathione-dependent enzyme activities in experimental otitis media with effusion in guinea pigs. Hum Exp Toxicol. 2005; 24 (11): 567-71. PMID: 16323573. doi: 10.1191/0960327105ht569oa

20. Stupin FP, Tatkov OV. General blood analysis. Information collection. Yekaterinburg: Publishing solutions, 2016.75 p. [Russian]

21. Kang DH, Kang SW. Targeting Cellular Antioxidant Enzymes for Treating Atherosclerotic Vascular Disease. Biomolecules and Therapeutics. 2013; 21(2): 89-96. PMID: 24009865. PMCID: PMC3762320. doi: 10.4062/biomolther. 2013.015 
22. Espinoza SE, Guo H, Fedarko N, DeZern A, Fried LP, Xue QL, Leng S, Beamer B, Walston JD. Glutathione peroxidase enzyme activity in aging. J Gerontol A Biol Sci Med Sci. 2008; 63(5): 505-9. PMID: 18511755. PMCID: PMC2964084

23. Fedets OM. Structure and functions of glutathione transferases. Ukr Biochem J. 2014; 86(3): 23-32. [Ukrainian] http:// dx.doi.org/10.15407/ubj86.03.023

24. López-Galindo C, Vargas-Chacoff L, Nebot E, Casanueva JF, Rubio D, Solé M, Mancera JM. Biomarker responses in Solea senegalensis exposed to sodium hypochlorite used as antifouling. J Chemosphere. 2010; 78(7): 885-93. PMID: 20022624. doi: 10.1016/j.chemosphere.2009.11.022

25. López-Galindo C, Vargas-Chacoff L, Nebot E, Casanueva JF, Rubio D, Mancera JM, Solé M. Sublethal responses of the common mussel (Mytilus galloprovincialis) exposed to sodium hypochlorite and Mexel432 used as antifoulants. Ecotoxicol Environ Saf. 2010; 73(5): 825-34. PMID: 20106525. doi: 10.1016/j.ecoenv.2010.01.001

УДК $577.3+615.9$

СТАН СИСТЕМИ АНТИОКСИДАНТНОГО ЗАХИСТУ В ЕРИТРОЦИТАХ ЩУРІВ

ЗА ДIÏ ГІСТАМІНУ ТА ГІПОХЛОРИТУ НАТРІЮ

Гарасим Н. П., Бішко-Москалюк О. І., Возняк М. В., Мандзинець С. М., Санагурський Д. І.

Резюме. Важливим $є$ вивчення безпечності застосування гіпохлориту натрію для лікування пацієнтів, які мають алергічні прояви, а значить і надмірне виділення гістаміну. Метою роботи є дослідити вплив гістаміну та гіпохлориту натрію, а також одночасну їхню дію на ензиматичну і неензиматичну ланки антиоксидантної системи еритроцитів щурів. Вивчали активність глутатіонпероксидази, каталази, глутатіон-Sтрансферази, вміст відновленого глутатіону. Проводили двофакторний дисперсійний аналіз. У еритроцитах щурів гістамін призводить до пониження активності досліджуваних ензимів та вмісту відновленого глутатіону впродовж досліду, крім 7-ї доби. Гіпохлорит натрію спричиняє першопочаткове зростання активності глутатіонпероксидази з наступним ії пониженням. Найменш чутливою до дії цієї речовини є глутатіонS-трансфераза. Гіпохлорит натрію на фоні дії гістаміну порушує роботу ензимів. На 1-шу добу досліду на активність глутатіонпероксидази, каталази і вміст відновленого глутатіону чинить головний вплив гістамін, тоді як на активність глутатіон-S-трансферази значно діє одночасне введення гістаміну і гіпохлориту натрію. Поєднане введення речовин справляє значний вплив на активність глутатіонпероксидази на 7-му і 14-ту доби досліду. На активність каталази і вміст відновленого глутатіону впливає гіпохлорит натрію.

Ключові слова: гістамін, гіпохлорит натрію, еритроцити.

УДК $577.3+615.9$

СОСТОЯНИЕ СИСТЕМЫ АНТИОКСИДАНТНОЙ ЗАЩИТЫ В ЭРИТРОЦИТАХ КРЫС

ПРИ ДЕЙСТВИИ ГИСТАМИНА И ГИПОХЛОРИТА НАТРИЯ

Гарасым Н. П., Бишко-Москалюк О. И., Возняк М. В., Мандзинец С. М., Санагурский Д. И.

Резюме. Важным является изучение безопасности применения гипохлорита натрия для лечения пациентов с аллергическими проявлениями, а значит и чрезмерным выделением гистамина. Целью работы является исследовать влияние гистамина и гипохлорит натрия, а также одновременное их действие на ферментативные и неферментативные звена антиоксидантной системы эритроцитов крыс. Изучали активность глутатионпероксидазы, каталазы, глутатион-S-трансферазы, содержание восстановленного глутатиона. Проводили дисперсионный анализ. В эритроцитах крыс гистамин приводит к понижению активности исследуемых ферментов и содержания восстановленного глутатиона в течение опыта, кроме 7го дня опыта. Гипохлорит натрия вызывает первоначальное повышение активности глутатионпероксидазы с последующим ее понижением. Наименее чувствительной к действию этого вещества является глутатион-S-трансфераза. Гипохлорит натрия на фоне действия гистамина нарушает работу энзимов. На 1е сутки опыта на активность глутатионпероксидазы, каталазы и содержание восстановленного глутатиона оказывает ведущее влияние гистамин, тогда как на активность глутатион-S-трансферазы значительно действует одновременное введение гистамина и гипохлорита натрия. Совместное введение веществ оказывает значительное влияние на активность глутатионпероксидазы на 7- и 14-е сутки опыта. На активность каталазы и содержание восстановленного глутатиона влияет гипохлорит натрия.

Ключевые слова: гистамин, гипохлорит натрия, эритроциты.

The authors of this study confirm that the research and publication of the results were not associated with any conflicts regarding commercial or financial relations, relations with organizations and/or individuals who may have been related to the study, and interrelations of coauthors of the article.

Стаття надійшла 25.06.2018 p. Рекомендована до друку на засіданні редакційної коледії після рецензування 